\title{
The Development of Problem-Based Learning Module for Writing Exposition Paragraphs for X Grade Students of SMA N 8 Padang
}

\author{
Rakafaeri, Syahrul Ramadhan, and Irfani Basri
}

\author{
Indonesian Language and Literature Education Study Program, Universitas Negeri Padang, $\square$ (email), \\ rakafaeri@gmail.com
}

\begin{abstract}
The background of the problem in this research is the teaching materials used have not been able to fulfil the needs of the exposition writing process. Therefore, a module need to be developed as one of the teaching materials to solve these problems. The purpose of this study was aimed at describing the process of developing a problem-based learning module (problem based learning) for the material of writing exposition paragraphs for $\mathrm{X}$ grade students of SMA N 8 Padang. It also was aimed at producing a problem-based learning module (problem based learning) for the material of writing exposition paragraphs for $\mathrm{X}$ grade students of SMA N 8 Padang that was valid, practical, and effective. This research was a Research and Development ( $\mathrm{R} \& \mathrm{D})$ using the 4D development model (define, design, develop, disseminate). The subjects of this research were 27 students of grade X of SMA N 8 Padang. The instruments of this research were the validation sheet of the problem-based learning module, the practicality questionnaire of the problem-based learning module, the performance test of the problem-based learning module, and the student observation sheet. The research data were the result of the validation by experts, the data on the practical results of the teacher and students, the effectiveness data in the form of student learning outcomes data and the results of student observation sheets.
\end{abstract}

Keywords: module, problem based learning, writing exposition paragraphs

\section{INTRODUCTION}

Teaching materials used have not been able tofulfill the students' needs in the exposition writing process. This is because the handbook that the students have from the contents of the learning material is still insufficient to provide knowledge to the students about learning of writing exposition paragraphs. The presentation and the display of the text are only given in the monotonous color-black color. It is less attractive and less motivating the students in the learning process. This brief analysis shows the need for an improvement process to support the exposition writing learning process. Based on the results of observations and interviews with the teacher of class $\mathrm{X}$ teaching Indonesian Subject, it is obtained that the students' exposition writing skills are still relatively low. The low student writing skills are due to the writing skill itself is often considered difficult by the students. Iskandarwassid and Sunendar (2008: 248), said that "compared to the three other language skills, writing ability is more difficult to master even by native speakers". The difficulty of writing activities is because writing skills require mastery of various other elements of language, and this skill requires a lot of practice.

The low ability of students in writing exposition paragraphs can be seen in the result of writing practice for students who have not fulfill the Minimum Completeness Criteria (KKM), which is below 80. It is often difficult for the students in expressing ideas or ideas, choosing effective vocabulary, writing paragraphs that coherent, and others. Besides, the limitation of teaching materials possessed by teachers is also one of the problems in learning of writing exposition paragraphs. it makes the teaching and learning process less optimal in the classroom. The teaching materials used are still less effective to create a creative learning. Teaching materials become one of the factors that influence whether the learning process can be effective or not. Teaching materials are anything that can support the learning process. Prastowo (2012: 17), said that teaching materials are all materials (both information, tools, and texts) which are arranged systematically, which display a complete figure of competencies that will be mastered by students and used in the learning process. The form of teaching materials according to Sunardjo (2008), consists of: (1) printed materials such as: handouts, books, modules, worksheets, brochures, leaflets, wall charts, (2) audio visuals such as: video / film (3) audio such as: radio , cassettes, CDs, (4) visuals such as images, models, models, (5) multi-media such as: interactive $\mathrm{CD}$, computer based, and internet. 
The low ability of the students to write exposition paragraphs and the limitations of Indonesian language teaching materials of SMAN 8 Padang encourages the researcher to create a problem-based learning module of the material for writing exposition paragraphs. The learning module is a systematically arranged material used by teachers and students in the learning process. The learning module is expected to facilitate the teachers in delivering the material and can be a guideline that directs all student activities in the learning process. The problembased learning module is a learning module developed by implementing problem-based learning stages. The module presents problems that are close to the students, and it is then related to the context of the material that the students will learn. Based on the problems presented, the students are required to do problem solving by digging as much information as possible, then analyzing and finding solutions to the existing problems.

The selection of modules as instructional materials was developed on the fact that the modules are arranged systematically and interestingly on the scope of the content of the material packaged in small units and completed with clear examples and illustrations, practice questions, assignments, having straightforward and communicative language; there is a summary of material content, as well as evaluation that allows students to learn independently and can measure their own abilities. Ismanto (2013) found that there is an improvement in the student activities and learning outcomes in using modules, so it is important for the teachers to make modules so that it will be easy for the students to understand the material and they can study it independently. Based on this fact, it is important to develop a teaching material in the form of problem-based learning module (learning based learning) for learning to write exposition paragraphs for $\mathrm{X}$ grade students of SMA N 8 Padang. The development of Problem-Based Learning Module is used to develop the valid, practical, and effective learning resources in writing exposition paragraphs. This module is expected to provide solutions for teachers and students in the learning process of writing exposition paragraphs.

\section{METHOD}

This research was a Research and Development ( $\mathrm{R}$ $\&$ D) using the 4D development model (define, design, develop, disseminate). The test subjects in this research were X grade students of SMA N 8 Padang. Some criteria or considerations for the selection of SMA N 8 Padang as the subject of the test were as follows: (1) the module has never been used by the teachers and the students in learning of writing exposition paragraphs, (2) the school environment supported the implementation of research, (3) the student characteristics were appropriate with the researcher's needs, (4) the schools are responsive and enjoyed about the development efforts undertaken. The data were quantitative data. The first data were the result of the validation of the problem-based learning module by the validator. The second data were obtained from a practicality questionnaire filled by the teachers and the students. The third data were the test data on the student activities and learning outcomes on the exposition writing material and the additional data were in the form of observation sheets.

To collect research data, the researcher used some instruments of the data collection. The instruments of data collection were questionnaires in the form of product validation sheets, practicality questionnaires, and performance tests to see the effectiveness of the problembased learning module. The questionnaires were arranged by using a modified Likert scale from Riduwan (2012: 13), using the following four alternative answers. SS (strongly agree), S (agree), TS (disagree), STS (strongly disagree). Before used, all the data collection instruments were validated by experts. The data from the instrument validation were processed by using a Likert scale. After the instrument was valid, the instrument was used for the third development process-develop.

The data analysis technique of the results of this research was conducted to determine the validity, practicality, and effectiveness of the problem-based learning module that have been made. The data from the research results were analyzed by using descriptive statistics which was describing the data as they were. The analysis of the module validity was done by experts. Then, the analysis of the module practicality was done by the teachers and the students. and the analysis of the module effectiveness. The analysis of the module validity based on Problem Based Learning (PBL) was made based on the results of content and construct validation obtained from the validation sheet. The practicality analysis of modules based on Problem Based Learning (PBL) can be seen from the practicality questionnaire that has been filled out by teachers and students. To analyze the questionnaire validation and practicality data, the following stages were carried out. (1) The answer given by the validator was based on a Likert scale, (2) the score was summed for each validator, (3) the calculation of the final result data of the validation results analyzed on a scale (0-100).

The analysis of the module effectiveness can be seen from learning outcome data and the student activity observation sheets. The student learning outcomes data were obtained from the cognitive learning outcomes in writing exposition paragraphs by the students. The assessment of the student work results were based on the assessment indicators and KKM that applied to a short story writing material in Grade $\mathrm{X}$ of SMAN 8 Padang. KKM which has been determined for short story writing material was 80. PBL-based modules were declared effective if $75 \%$ of the student learning outcomes were above the KKM. To analyze the data collected from the observation sheet, an analysis of student activities was carried out by using an observation sheet. It was done by calculating the percentage of student activity in each aspect observed using the percentage formula and calculating the mean by summing all the percentage of student activities from all aspects divided by the number of observed aspects. Finally, it was done by qualifying the mean of the percentage that has been obtained in 
appropriate with the criteria used to determine the level of success of the student activities.

\section{RESULTS AND DISCUSSION}

This development research produced a teaching material in the form of a module based on Problem Based Learning (PBL) for writing exposition paragraphs. The design module for writing exposition paragraphs developed has been adapted to the structure of making a module. To get a valid, practical and effective model, the validity, practicality and effectiveness tests are carried out. The validation is very important to know the validity of the module before being tested in learning. In addition, the validation is very important to get an assessment of the module. This is appropriate with the opinion of Daryanto (2013: 22) which states that validation is a process to test the suitability of modules with competencies which are the learning objectives. The module that has been designed was validated by experts. The validating expert is a lecturer at UniversitasNegeri Padang. The validation activities are carried out by filling in the validation sheet and discussion with the validator. The validated modules must fulfil the criteria for validity in terms of presentation, content feasibility, language feasibility, and graphics. The four aspects of validity are stated in the Ministry of National Education's book (2008: 28)

\section{The Validation of the Problem Based Learning Module (PBL) for Writing Exposition Paragraphs}

Based on the analysis conducted on the module validation questionnaire, the score obtained was 468 . The validity result of the developed learning module reached the level of $69.90 \%$. The validity categories were valid. This shows that the module writing the PBL-based exposition paragraph has been able to be tested. The four aspects in the module: content feasibility, language feasibility, presentation feasibility, and graphic feasibility were valid. The following describes the percentage result of each aspect of the feasibility. Based on the analysis carried out on the module validation questionnaire on aspects of content feasibility, the learning module developed specifically in the aspect of content eligibility reached $63.10 \%$. The validity category of the module from the aspect of content eligibility was valid. The accuracy of the module with the curriculum, the accuracy of the concepts, and the substance of the module have been good. The percentage of language feasibility aspects reached $78.10 \%$. The validity category of the module from the aspect of language feasibility was valid. The sentence layout, ideas and delivery style in the module were good. Based on the analysis conducted on the module validation questionnaire on aspects of the feasibility of presentation, the learning modules developed specifically on the aspect of feasibility of presentation reached the level of $77.50 \%$. The validity category of the module from the aspect of presentation feasibility wasvalid. The presentation was appropriate with Competency Standards (SK), Basic Competencies (KD), indicators and learning objectives. Based on the analysis carried out on the module validation questionnaire on the feasibility aspects of graphics, the learning modules developed especially on the feasibility aspects of the graft reached the level of $61.90 \%$. The validity category of the module from the graphic feasibility aspect was valid.

\section{The Practicality of the Problem-Based Learning Module (PBL) for Writing Exposition Paragraphs}

The practicality of theproblem-based learning module (PBL) for writing exposition paragraphs was known after conducting a field trial. According to Daryanto (2013: 51-52) the intended trial is to test the draft theproblem-based learning module (PBL) for writing exposition paragraphs that have been validated to some sample students. In this research the sample practicality of theproblem-based learning module (PBL) for writing exposition paragraphswasthe teacher and $\mathrm{X}$ grade students of SMA N 8 Padang. This practical test was carried out after the teacher and the students used and learnt the module to write a PBL-based exposition paragraph. The teacher and the students were asked to fill out a practical questionnaire in theproblem-based learning module (PBL) for writing exposition paragraphs. Thus, the results of the practicality of theproblem-based learning module (PBL) for writing exposition paragraphs consisted of two types: the practicality of theproblem-based learning module (PBL) for writing exposition paragraphsby the teacher and the practicality of theproblem-based learning module (PBL) for writing exposition paragraphs by students. Both of these are explained below.

\section{a. The Practicality of the Problem Based Learning Module (PBL) for Writing Exposition Paragraphs by Teacher / Practitioner}

When viewed from the results of the analysis of the practicality questionnaire by the teacher / practitioner, it can be concluded theproblem-based learning module (PBL) for writing exposition paragraphs entitled Being Skilled in Writing Expositionfor SMA N 8 Padang was easy to use in learning to write exposition paragraphs. The time specified in the curriculum was according to what was stipulated in the PBL-based exposition writing module. This can be seen from the results of practicality by the teacher of $73.50 \%$. Thus, it can be concluded that theproblem-based learning module (PBL) for writing exposition paragraphsthat has been developed is easy to use by the teacher in learning, and the teacher are enjoyed to use it because the presentation style is interesting and the material presented is also good. Learning by using the module is more effective and efficient so that it can help teachers deliver lessons while making time effectively. Economically, this module is easy to carry. Thus, problems in learning to write exposition paragraphs in the class can be overcome by using the PBL-based exposition writing module that has been developed. 


\section{b. The Practicality of the Problem Based Learning Module (PBL) for Writing Exposition Paragraphs by Students}

When viewed in terms of practicality according to the students, the PBL-based exposition paragraph writing module entitled Being Skilled in Writing Exposition was in a practical category. This was based on the results of practical questionnaire analysis by the students of $75.80 \%$ with practical categories. If it is associated with the practicality indicators, it can be interpreted that the PBLbased exposition paragraph writing module that have been developed is easy to use by the students in learning. The presentation of the module is interesting, and it makes it easier for the students to use the module in learning. In addition, the good quality of the module makes the students enjoyed to use it. Based on the results of the analysis of the practicality of theproblem-based learning module (PBL) for writing exposition paragraphs by the teachers and students, it can be stated that the module that has been developed can be used by teachers and students in learning to write exposition paragraphs. This is based on the results of practicality tests which show that the module that are developed in a practical category. In other words, the module is easy to use by teachers and students in learning.

\section{The Effectiveness of the Problem Based Learning Module (PBL) for Writing Exposition Paragraphs}

After practicing the practicality test on theproblembased learning module (PBL) for writing exposition paragraphs that was developed, the effectiveness of the module was analyzed by writing the PBL-based exposition paragraphs. The results of the effectiveness came from the result of the observations of the student activities while studying by using the moduleand the student learning outcomes on the tests given after studying by using the module. To be clearer, both of these will be explained below.

\section{a. Student Activities}

During the learning process using theproblembased learning module (PBL) for writing exposition paragraphs, the student activities were always observed. The activity indicators targeted for the observation were 5 activities. The five indicator activities are presented as follows. First, it was about the students' attention in learning by using the module. Second, the students learnt the material in the module and did things that were relevant to the learning material. Third,the students work on all understanding tests and performance tests in the module. Fourth, the students had discussions with friends. Fifth, the students matched the answers with the essence of the answers to find out the level of their understanding and did self-assessmentappropriate with the assessment rubric provided in the module. The student activities were observed by the researchers themselves and other observers. To facilitate observations, the observer divided the test class into an observation group. The division was based on the student seating. Based on the results of the questionnaire observation analysis, the results showed that in general, the student activities were classified as very active. Based on the results of the analysis of student activities, it can be concluded that theproblem-based learning module (PBL) for writing exposition paragraphs entitled Being Skilled in Writing Exposition is very effective with an average activity result of $88 \%$ with good criteria and success rates. Thus, theproblem-based learning module (PBL) can be used in learning to write exposition paragraphs specifically, and learning Indonesian in general.

\section{b. Student Learning Outcomes}

Student learning outcomes in studying the material of writing exposition paragraphs can be seen from the tests given to students. Based on the analysis of the results of the scores and test scores for work, it was concluded that the experimental class students were generally in a good qualification (B) with an mean score of 79.85 , and the percentage that reached the KKM 80 was $81.48 \%, 22$ students who reached the KKM from 27 students. This result has fulfilled the completeness requirements in studying thePBL-based exposition paragraph writing module which was $>80$. Looked from the individual abilities, there were still 5 students who have not been reached the target based on the learning criteria through the PBL-based exposition paragraph writing module. This incompleteness was caused by the results that have not fulfilled the minimum completeness criteria to learn about the module. The students who have not fulfilled the criteria have low scores because they have not mastered the concept of the learning material in writing exposition paragraphs and have not been trained in writing.

After the validity test, practicality test, and effectiveness test were described, it can be stated that the PBL-based exposition paragraph writing module with the title "Being Skilled in Writing Exposition" based on PBL was included in the valid category because the validity resultwas $69.9 \%$. The PBL-based exposition paragraph writing modulewas practice because the practicality result of the module by the teacher was $73.5 \%$, and the practicality result of the module by the students was $75.8 \%$. Furthermore, the module was effective because the result of the student learning outcomes performeda mean performance test of 79.85 with sufficient qualifications (C). That means that teachers and students can use the module on learning,specifically, to write exposition paragraphs, and learning Indonesian in general. The conclusion as a whole is based on the opinion of Riduwan (2012: 15) which states that results that are at intervals of $76-85$ are categorized as valid and practical. Meanwhile, Dimyati and Mudijono (2006: 125), student activities are on very active criteria if the percentage of activity is at $76-100$.

\section{CONCLUSIONS}

Based on the results of the research and discussion in this research, it can be concluded as follows. First, theproblem-based learning module (PBL) for writing exposition paragraphsfor $\mathrm{X}$ grade students of SMA N 8 Padang is designed to be classified as valid. The module for writing exposition paragraphs can be used by teachers 
and students. The validity of the module in writing exposition paragraphs is seen from four aspects, as follows. In the aspect of content eligibility, the module refers to SK, KD, and indicators contained in the SBC and the learning presented have included the PBL stage. The material in the module can be used by the teacher in learning, especially in the subject of exposition paragraph writing. In the aspect of language feasibility, the module appropriate with EBI, is easily understood by the students, and arouses the enthusiasm of the students in learning. The language used in the module can be understood by the teachers and the students. In the aspect of presentation feasibility, the module appropriate with the curriculum is easy for the students to understand, increase the enthusiasm of the students, and appropriate with the progress of the times. The presentation of the module can be used by the teachers and students. In the graphic aspect, the module is easy to read and can arouse the activities of the students. The integrity of the module can be used by the teachers and the students.

Second, the problem-based learning module (PBL) for writing exposition paragraphs for $\mathrm{X}$ grade students of SMA N 8 Padang is designed to be practical. The module can be used by the teachers and the students. The practicality of the module is seen from two aspects, as follows. In the aspect of the easy use, the module is easy to use for the teachers and the students. The teacher no longer needs to look for other references in learning because the material in the module has been clear and easy to understand. The students can learn easily even though there are no teachers and students can study anywhere. In the aspect of conformity with time, the module is designed according to the time set in the 2006 curriculum or KTSP.

Third, the problem-based learning module (PBL) for writing exposition paragraphs for $\mathrm{X}$ grade students of SMA N 8 Padang is designed to be very effective in generating activities and learning outcomes of students. It was seen from the observations made by observers who stated that when learning to use the module writing paragraphs all the students looked active and the results obtained were generally well categorized.

Based on the conclusions of this research, the suggestions obtained appropriate with the results of the research are as follows. First, the principal should advise teachers to make their own teaching materials for learning so that learning is more meaningful. Second, the teachers should be able to make additional teaching materials so that the learning material taught can be conveyed well to students. Third, the researcher can use the results of this study as relevant research and if teachers want to develop teaching materials, they should develop teaching materials with different materials.

\section{ACKNOWLEDGMENTS}

The author would like to thank you for the Prof. Dr. Syahrul R , M Ed ., and Dr. Irfani Basri , M.Pd. , As the supervisors I and II who have provided input, insight, views, and direction that greatly helped the author in completing this journal. Thank you to Prof. Dr. A tmazaki
, M.Pd. , Prof. Dr . Yasnur Asri , M Ed ., Dr. Ramalis Judge, M Ed ., As the validator instrument and product research that has been giving advice and referrals to repair the instrument and product research. Thank you to Desmiarti, S.Pd. as a grade X Indonesian language teacher who has helped and accompanied the writer during the research process. Thank you to DAY SPSS for helping with the research data processing. Thank you to both the parents of the writer Mother Fauziah and Aniswardi's father. which has funded all research processes.

\section{REFERENCES}

Dimyati and Mudjiono. 2006. Studying and Learning. Jakarta: RinekaCipta.

Daryanto. (2013). Module Building (Teaching Materials for Teacher Preparation in Teaching). Yogyakarta: Gava Media.

Iskandarwassid and DadangSunendar. (2008). Language Learning Strategies. Bandung: PT RemajaRosdakarya.

Ismanto, Hadi. (2013). "The Development of Class IV Elementary Education Civics Module Main Subject to Character Educator Globalization". Journal of Primary School Education (online)

Vol 7. No 1. Accessed 11 December 2014.

Ministry of National Education. 2008. Guide to Development of Teaching Materials. Jakarta: Directorate of High School Development.

Prastowo, A. (2012).Creative Guide to Making Innovative Teaching Materials. Yogyakarta: Diva Press.

Riduwan .(2012).Measurement Scale Research Variables. Bandung: Alfabeta.

Sunardjo. (2008). Form of Teaching Materials. http://www.slideshare.net. Accessed onAugust 28, 2014. 